\title{
An exploration of the information literacy experiences of home educating families
}

Jessica Elmore, Peter Stordy

\section{Abstract \\ Background and aims}

There is limited existing research on the information literacy experiences of home educating families. This study aims to explore these experiences, providing a framework and context for their experiences and finding parallels in the existing literature on information literacy.

\section{Methodology}

This is a qualitative study consisting of five in-depth interviews with families. The findings were analysed using a grounded, interpretive approach.

\section{Results and conclusion}

The findings suggested that digital aspects of information literacy were significant for these families and that communities of practices were a useful way to understand their information literacy. The importance of reflection for information literacy was also demonstrated. There was some evidence that the information literacy of home educating families could be seen as challenging the orthodoxy of more formal educational models.

\section{Introduction}

Information literacy (Johnson, Sproles and Detmering, 2013; Bawden, 2001) and home education (Rothermel, 2002) have gained increasing currency over the last three decades in the United Kingdom. While the information literacy experiences of home educated families have never been explored in any detail there is a strong

\section{Authors}

Jessica Elmore is a $\mathrm{PhD}$ student at the Information School, University of Sheffield. She is researching the information literacy experiences of ESOL (English for Speaker of Other Languages) learners.

Email: jrelmore2@sheffield.ac.uk

Peter Stordy is University Teacher at the Information School, University of Sheffield. In addition to supervising postgraduate students, he is Director of Learning and Teaching. 
narrative within home education research that suggests it offers markedly different information experiences to school based learning (Meighan, 1995). This study therefore attempts to add to this research by developing a framework to better understand these perceptions and experiences. Equally the research aims to increase our understanding of information literacy by exploring it in a new environment (Tuominen, Savolainen and Talja, 2005). This research therefore aims to explore home educating families' information literacy experiences, developing a framework to capture these perceptions, providing individual home educating families with a context for their own information literacy experiences and exploring the relationship between existing models of information literacy and home educating families' information literacy.

\section{Literature review}

\subsection{Home education in the United Kingdom}

Home education is legal in all of the United Kingdom and home educators have considerable freedom particularly in comparison to many other European countries (Blok and Karsten, 2011). In England and Wales parents and carers have a duty to provide their children with a suitable education but there is no indication of what is a "suitable education" (Monk, 2004) and they do not have to register or prove that they are providing such an education (Education Act, 1996, s437-443). This status has been criticised (Monk, 2004; Badman, 2009) but is fiercely defended by many home educators (Select Committee on Children, Schools and Families, 2009). There is different, but similar, legislation in Scotland and Northern Ireland.

As there is no system of registration there are no reliable figures about the number of home educated children in the UK. Estimates of the current number in England vary between 45,250 and 150,000 (Hopwood, O' Neil, Castro and Hodgson, 2007). However, there is general agreement that this figure has risen consistently since the 1970's when UK home education in its current form is said to have started (Kunzman and Gaither, 2013; Fortune-Wood, 2005). There is also no reliable information about the demographics of home educators although research suggests they are a diverse group encompassing, for example, Roma families, religious home educators, and those who engage private tutors (Rothermel, 2011; 2002). The reasons families choose to home educate are equally diverse (Morton, 2011; Gabb, 2005). There does however seem to be one commonality: that "mothers were often the parent most involved with the day to day running of the children's education" (Rothermel, 2011, 25). The role of the mother therefore needs to be considered in a study of home education; how she becomes an educational professional (Gaither, 2009); how she constructs home education (Morton, 2010) or the sacrifices she makes (Lois, 2006). Her central role may however also reflect more general parenting norms; the undergraduates in Gross and Latham's study (2009) saw their mothers as an important part of their formative information literacy experiences.

Home education is perceived as a "growing phenomenon" (Morton, 2011, 9) in the United Kingdom and this is reflected in the increasing literature on the subject. However, a considerable proportion of this is written by home educators, for 
example, Dowty (2000), Fortune-Wood (2000) and Meighan (1992) and often serves as practical guidance or encouragement. Kunzman and Gaither's (2013) systematic review of the emerging literature shows that most research is from the United States and much of it is advocacy-based with little or no large scale quantitative research. Hanna's (2012) research is one of the few longitudinal studies of home educators in the United States and offers a valuable picture of how the Internet has transformed home education; as well as how children tend to move away from the family to other networks as they grow older.

\subsection{Home education and learning}

There is also limited research on the kinds of learning seen in home education. What is known is that there is a continuum of learning styles from a structured programme, similar to that followed by schools, to an education without a timetable, curriculum or fixed outcomes (Thomas and Pattison, 2012). The latter style described here is generally known in the UK as autonomous education. Thomas and Pattison (2007) emphasise the importance of what they refer to as informal or autonomous learning and base their evidence on observation and interviews with a large number of families. They use theories of lifelong learning to exemplify how children learn; there is an emphasis on the practical, on process, on chance and on the social and emotional which they see as markedly different from school-based learning. This description of autonomous learning has much in common with Holt's (1991) influential discursive accounts and is the focus of much home education research. However, as Arora's (2002) research shows, it is important to remember there is a continuum; many families do follow structured programmes. There is however evidence that families tend to move from structured to unstructured learning (Hanna, 2012; Thomas and Pattison, 2007).

Studies from the United Kingdom (Rothermel, 2002) and more extensively from the United States (Ray, 2010; Rudner, 1999) have shown positive academic outcomes for home educated children. However, Kunzman and Gaither (2013) and Webb (2011) have argued these studies do not show a positive effect once socio-economic factors are taken into account. It is outside the scope of this study to examine this area in detail but it is necessary to note the lack of certainty in this, as in all areas of home education. Three North American studies written from outside the home educating community demonstrate this giving a varied picture of academic outcomes (Martin-Chang, Gould, and Meuse, 2011; Pennings, 2011; Cogan, 2010). Writers such as Holt $(1991,1977)$ challenge the very notion of measuring outcomes in this way and so we also need to look more holistically at home education. In this way research such as Webb's (1999) narratives, which look at the long term outcomes for the home educated such as a passion for lifelong learning, complement quantitative studies of baseline assessments.

\subsection{Information literacy}

Information literacy is similar to home education in that it resists definition and can be seen as a contested term (Savolainen, 1993). Herring's $(2009,3)$ description of information literacy as "a way of thinking" and Bawden's (2001) conclusion that in today's society we need complex broad literacies no matter how we define them are both appealing statements. However, unless it is 
contextualised there is a danger that information literacy means everything and nothing and so we still need to find a working definition. The model of information literacy as a set of skills and abilities (SCONUL, 2011; ACRL, 2000) has been comprehensively challenged most notably by phenomenographic (Webber and Johnston, 2000; Bruce, 1997), discourse (Kapitzke, 2003) and sociocultural approaches. It is this latter communicative approach that is adopted here.

The communicative approach sees information literacy as a social practice (Tuominen, Savolainen, and Talja, 2005). Lloyd (2010) argues that information literacy needs to be seen as a meta-practice that only exists in its particular context and that we need to look beyond education to find new information literacy landscapes. She shows that workplace and community landscapes challenge rationalist skills-based interpretations of information literacy. This approach informs much of the current study as it is concerned with the participants' constructions of their information literacy practices in a previously underexplored landscape. Lupton and Bruce (2010) argue that information literacy has three perspectives; the generic (skills based); the situated (socially constructed) and the transformative. This third perspective contains within it the generic and situated but extends to a model of information literacy as a critical practice. In this way they consider information literacy to have the potential to empower individuals and groups and challenge existing power relations. This model of a critical information literacy (Kapitzke, 2003) as well as Lipu's (2010) argument for a feminist approach that considers information literacy in localized and everyday contexts seem to have relevance here. Home educators can be seen as a minority group operating outside of cultural norms and so these perspectives could add to our understanding of their practices.

\subsection{Wider research on related literacies}

This research is concerned with information literacy but the analysis of the interviews revealed that digital information was of central importance to the families interviewed. The significant body of research on digital literacy cannot be engaged with here but needs to be acknowledged. In this study, digital literacy is therefore used as a focus to conceptualise those aspects of information literacy that relate to the digital world. This is in line with Tuominen, Savolainen, and Talja (2005) who argue that information literacy needs to be understood in terms of the interplay of learning, knowledge formation and information technology. There is also significant research that looks at the information practices of school attending children both in and out of school that can help our understanding of home educating families. To briefly summarise, information literacy in schools is characterised as fact finding with a lack of autonomy, collaboration and reflection, although more meaningful tasks mean that information practices become more sophisticated and children become more reflective as they become more proficient (Herring 2011,2010, 2009; Hongisto and Sormunen, 2010; Meyers, Nathan, and Saxton, 2007; Limberg and Sundin, 2006). Research on children's digital practices at home tends to see these practices as more collaborative and the home potentially as a better environment for developing digital literacy (Davidson, 2012; Johnson, 2010; McTavish, 2009). There is also wider research on children 
and information behaviour which can help to contextualise this study. Children in the UK are typically regular users of the Internet (OFCOM, 2012) and identify books, people and computers as their main information sources (Shenton and Dixon, 2003).

\subsection{Home educated children's information literacy}

Thomas and Pattison $(2007,145)$ never use the term information literacy but look at home educated families' information practices as part of their study of informal learning. The children are self-directed learners: "they don't take in information they put it together... pull it apart again". Textual sources are not privileged and conversational learning has a central role. Their relationship with their parents is an apprenticeship but their parents are also their co-learners and mediators. Good information seeking skills also play a central role and informal learning is likened to new knowledge formation. Thomas and Pattison $(2012,152)$ argue that a community of practice provides a useful way to understand how home educated children learn. They conclude that:

Our research challenges the view of learning as a separate, definable, deliberate activity and suggests that learning itself needs to be problematized in a very radical manner.

This statement has much in common with Lloyd's (2005) view of how workplace information literacy challenges the neatness of formal academic models.

Safran $(2008,245)$ also writes of home educating parents as a community of practice through the common "joint enterprise of educating their children, mutually engaging and developing a shared repertoire". She shows how newcomers are apprenticed into a home educating community, explores the different ways parents identify as home educators and shows how parents are transformed by home education. Wenger (1998) defines a community of practice as people with a common interest who learn together how to do it better. Within this they must have a shared identity, shared activities and a shared set of tools and this seems likely to be a useful way to frame home educating families' perceptions of information literacy.

\section{Methodology}

\subsection{Constructivist grounded approach}

This research was intended to follow the principles of constructivist grounded theory (Charmaz, 2006) as an inductive research method that starts with data and through a process of coding moves towards the generation of theory. Charmaz's significant and contested break from earlier grounded theorists (Glaser, 2002; Glaser and Strauss, 1967) is her move towards an interpretive perspective; theories are not hidden in data but constructed through the researcher's perceptions, practices and interactions (Charmaz, 2006). However, this study diverges in several important respects from Charmaz's work most significantly in that theoretical sampling and saturation was not used. This was due to the limited time frame of the research. In this way while the research is constructivist it should be seen as grounded analysis rather than grounded theory (Herring, 2010). 
The researcher recognises her own role in the process of the "mutual shaping" of the participants' constructions of their own information literacy practices (Guba and Lincoln, 1985). The interview and the research therefore become a "negotiated text" where all are involved in the "meaning-making process" (Holstein and Gubrium, 2004). The research has an affinity with child-centred (Dell Clark, 2011; Christensen and James, 2008) and feminist research methods (Edwards and Mauthner, 2012) which emphasise the importance of giving a voice to the participants as well as adapting a reflexive stance as a researcher. The researcher took some steps towards participatory research; she consulted with home educating families before starting the project, gave interviewees their transcripts to edit and to comment on, and disseminated her findings to participants but this was not fully realised. In this way, the initial meetings with home educating families were useful in providing context but these encounters did not significantly shape the research questions. Two parents reacted positively to the transcripts but no family made any significant comments.

\subsection{The participants and the interviews}

Participants were recruited through a mailing list and informal visits to local groups. The research project was carried out on a part-time basis over an academic year and the recruitment and interview process took place between November and May. There was an initially slow response to the request for interviewees. However, a tipping point was reached when one interviewee shared her positive experience of being interviewed on the mailing list and encouraged other families to come forward. Other researchers have commented on the difficulty of recruiting participants from home educating communities particularly for those researching from the outside (Kunzman and Gaither, 2013; Morton, 2011; Hopwood, O' Neil, Castro and Hodgson, 2007). It therefore represents a considerable achievement and privilege to have gained access to the lives of these home educating families.

The research consisted of five in-depth interviews with individual home educating mothers and their children aged between eight and seventeen. Intensive or active interviews can be seen as the most significant way to explore participants' subjective realities (Miller and Glassner, 2011) and as fitting well with constructivist grounded theory (Charmaz, 2006). However, observation (Hongisto and Sormunen, 2010) or visual methods (Dell Clark, 2011; Smith, 2010) would also have been effective methods to explore young people's information literacy practices.

The interviews lasted between sixty and ninety minutes. The questions drew on those asked by Bruce (1997) and moved from narrative through discussion to reflection (Charmaz, 2006). A list of potential interview prompts was prepared in advance and is included as a Supplementary File. However, these prompts were only the starting point for open ended conversations. The most productive question for all interviews was the concluding one: "is there anything else you want to tell me?" The success of this question demonstrated that some of the other questions were unsatisfactory possibly either too technical or too tangential. In one interview Joanne, a mother, was able to re-phrase questions for her children far more effectively than the researcher could. 
A different interview method would have produced different results; a child interviewed alone is a different child when interviewed with her parent (Lewis, 2009). The complexities of using group interviews should not be under-estimated but as the family rather than the individual lies at the heart of this research, it is fitting that the research method mirrors this (Mayall, 2008). This method also shaped the research findings showing how families construct information literacies together (Kitzinger, 1995). The potential richness of these encounters was not fully realised in this current project; further analysis of non-verbal interactions, impressions and feelings would have added much to the richness of the data (Wilkinson, 1998).

\subsection{Analysis}

The interview transcripts were the texts used for analysis. The analysis took place between May and June and the results were written up in July and August. The researcher followed the process of analysis outlined by Charmaz (2006) moving from initial to focused codes and then to categories. The process of coding was challenging: one difficulty was a reluctance to move beyond the participants' voices to a more analytical level and another was maintaining a stance of "theoretical agnosticism" (Puddephatt, 2006) while also developing a reflexive understanding of the situated and subjective position of the researcher (Mauthner and Doucet, 2003).

\subsection{Ethics}

The ethics of research with a vulnerable group such as children extend far beyond the procedural (Miller and Bell, 2002). Care was taken to ensure the children gave their own explicit consent (Lewis, 2009) and the children were only interviewed with their parent. The hierarchical, formal boundary of interviewer and interviewee was not appropriate for these encounters. The researcher tried to make the interview a safe space and had to quickly gain the trust of the children while being aware of the ambiguities of fake rapport (Duncombe and Jessop, 2012). One essential ethical consideration was to make the interviews and the research process as a whole a positive experience for participants (Oliver, 2010).

\section{Findings}

Three major themes emerged from the analysis and these are discussed below. This is exploratory research and so the relationships between these themes are not fully developed. These are also findings which are about the experiences of these particular families in the context of this particular project. The names are all pseudonyms.

\subsection{Digital minds: central importance of digital information}

All the families saw computers, primarily the Internet, as central to their information landscapes. The young people in particular saw using the Internet as so ubiquitous that it resisted definition: "I don't really know because I use it all the time... for absolutely everything" (Eleanor). The Internet was a source of information in multiple formats but age seemed a significant factor in how the children used the Internet. Stan, twelve, saw the Internet as a place to synthesise 
information; a key word for him was "sources". Eleanor, seventeen, was more actively engaged describing herself as part of online communities. Some younger children still used social media but their experience was mediated through their parents "at the moment she types through my Facebook to her friend's mum's Facebook" (Karen).

The Internet then seems to mediate the home education experiences of these families (perhaps unsurprisingly as they were recruited through a mailing list). All the families described ready access to technology including laptops or computers as well as possibly e-readers, tablets and smart phones. There was also evidence that the mothers saw themselves as part of an online community. They were all active users of the Internet; they planned, organised and shared their experiences as home educators using a range of Internet tools. They then mediated this knowledge to their children.

The young people displayed pride in their experience of using technology and expressed the belief that home education provided valuable opportunities for digital learning. Mia remembered using computers at school:

We were told to use the website and we'd just guess, click on something funny and then do anything else.

She contrasted this sharply with her perception of how she used computers at home. The young people were overwhelmingly positive about their Internet use with only Stan cautioning about "wasting time on rubbish" when discussing YouTube. However, there was more parental ambivalence. Three out of the five mothers expressed concerns. Karen cautioned that "sometimes you get that [the computer] on and you can't get off it" and Siobhan commented "that's the other thing if it isn't on the internet they can't be bothered". Internet use was defined in a series of binary oppositions: it saved time while it wasted it; it caused information overload whilst being a mine of information, it was easy to use but needed to be carefully taught.

The ubiquity of the Internet meant that the families initially found it difficult to talk about their digital literacy. As Emma, a mother, said, "Libraries are a step back [from the Internet] ...usually it's very difficult to find information in a library." This suggested that digital access to information seemed intuitive while physically accessing information from a library required conscious effort. However, within the narrative of the interviews there was a point when some of the children seemed to shift from a view of digital literacies as natural to consider the strategies they used. During one interview, Eleanor moved from seeing her Internet skills as obvious and needing no explanation to clarifying her strategies reflected in a change of language from the repetition of the word "just" to more hesitant phrases such as "I suppose so". The young people all talked about a range of strategies: looking for recommended or trusted sites, scanning front pages, using key word searches, assessing for relevance and considering bias. These strategies seemed to have been developed within the individual families learnt by observation and explicit teaching as well as by experimentation. There was then evidence that families constructed their digital literacies, "so that for us that became the way to do it" (Joanne) and shared their practices. 
Within the world of the interview, the young people therefore moved to a conscious recognition of their digital literacies. The idea of the interview as a learning moment can also be seen at other points when, for example, Eleanor and her mother discussed the merits of Google Scholar, building on their own family information literacy rather simply providing information for the researcher. Some of the family's perceptions of information literacy are therefore constructed within the interview.

\subsection{Information literacy in the wild: challenging the skills model}

The concept of information literacy as information skills was important for the participants and the researcher. It offered a way to understand and organise thoughts and feelings about information literacy. Within the discussion of skills, the processes of information seeking dominated for both interviewer and interviewees. However, participants talked about a range of different information experiences. For example, in Isla's interview she talked about her searching strategies, the difficulty of synthesising information and the need to write for a particular audience "(what) we have to do is get it off the Internet but put it down in our words".

There is then a world of expertise and high order critical skills that participants draw on both as ways to conceptualise their experiences and to demonstrate that they are information literate. Joanne, a mother, explains "it's a case of just keeping on top of it making sure she knows how". This reliance on an information skills model possibly reflects the difficulty for all participants in talking about information literacy. In the same way, the researcher had no intention to assess participants' information skills but her questions were still sometimes mediated through an information skills model.

However, there are points within each interview when the dominance of the skills model is questioned and challenged. While participants highlight information skills that are necessary and useful, they also all draw on their experiences of "tick[ing] boxes" (Siobhan), "jumping through hoops" (Eleanor), or "play[ing] the system" (Emma). Siobhan articulated this most strongly contrasting school-based practice where the emphasis is on the final product with the practices of her children.

All the families interviewed told of information literacy experiences that were outside of this skills approach. There was a strong emphasis, particularly amongst the autonomous families, of hidden learning. Mia commented "we learn things when we don't know it" and this motif was repeated across the families.

You'll think they're doing nothing very much and suddenly they'll come out with something they've learnt from somewhere and you'll think where have they got that from?

(Karen)

This is reflected in how the mothers discussed teaching, or perhaps more accurately, not teaching their children. There is an emphasis on a natural process where young people are provided with opportunities to be information literate rather than formally taught. With this comes a tension between whether home 
education is hard work or whether "it's nothing much really" (Eleanor) both for the young people and for the parents. This was expressed by Karen as "you're constantly clutching at straws trying to find something they'll like and they're interested in" which captures how the mothers seem to work hard to provide learning opportunities that are then seen as natural.

Families also talked about a holistic approach to information practices where the emphasis was on putting things together and following on: "It's made me realise that you do gather stuff from so many different places" (Siobhan). The families who weren't autonomous still described the importance of holistic experiences and emphasised serendipity or chance. It was clearly important for these families to construct their experiences this way, putting an emphasis on the holistic and the natural rather than on prescribed learning. Siobhan, looking back at her children's education, comments "it's nice how rounded it's become in the end."

There was an emphasis that these practices were very different from the fact finding behaviour in schools: "we don't go home; we carry on through our lives" (Joanne). The information experiences of home educating families were perceived as being like life rather than based on artificial exercises. Learning was done in context; an interest in dinosaurs or Harry Potter, or a visit to Hampton Court were the catalysts for further experience. The family who followed the national curriculum displayed most evidence of school-based practice and the most interest in fact-finding, of getting the right answer. However, they still saw their practices as different and better than those taught in school.

Whereas I believed everything the school was doing and I didn't really have an issue with the schools suddenly I find actually that they think differently now.

(Emma)

In all the families, there was a strong emphasis on the child as confident and independent in learning and information literacy. Eleanor expressed the views of many "I've always pursued everything on my own". Both parents and children narrate experiences where the child is a confident researcher ("when I ask them to find something themselves they come to me with information that I haven't even thought of" (Joanne)), who is responsible for their own information needs: "the things that she's interested in we spend hours doing" (Siobhan).

There was also recognition of an information world away from formal education. There was an emphasis on the practical; of real tasks such as planning and cooking a meal; learning origami; making a dress; performing a play, climbing and ice skating. These were to a lesser or greater extent seen as information literacy experiences. The exploration of information literacy in the wild was strongest in the autonomous families, but all emphasised literacies as a practice for life rather than just education.

\subsection{Doing it together: the importance of collaborative information practices}

Within each interview, there was evidence that the young people's information literacy experiences are also mediated by people who could be seen as three groups: experts, families, and communities. This is of course only a loose classification based on five families but it is a way to understand their experience. 
Experts such as teachers or tutors were the least significant of these groups. The two young people who were studying post sixteen had moved to college and those who had studied or were planning to study GCSE's were likely to use tutors. The role of the tutors however seemed to be to "tick the boxes" and their importance was played down.

Fathers also played an interesting role, often seeming to act as a bridge between the outside world of the expert or tutor and the internal family information literacy practices. The father draws on a different body of knowledge from outside the home and brings this back to the family. Karen commented:

when I don't know I used to say ask daddy because he knows a lot more or if we're in the house it's let's look it up, I don't know the answer.

The mother as the main home educator plays a central role in the family's information practices. However, her role seems to be downplayed in many families and her work is hidden; she leaves "stuff lying around" (Karen), she facilitates and creates opportunities. She is not undervalued: "she's a brilliant teacher and finds excellent books for us" (Isla), but her role is in the background. Two children reacted with humour to the idea that their mother could help them with a subject. There is an emphasis either on partnership: "we'll see how that goes, we'll get on with that now" (Emma), or, as mentioned above, on the child as the leader.

However, the mother does mediate her children's information experiences. One manifestation of this is the issues surrounding control, censorship, access and privacy. This was a slightly sensitive area often treated with humour. Attitudes varied between families from "we didn't ever censor access" (Sarah) to a concern to demonstrate to the researcher that there were boundaries "that's not age appropriate" (Emma). Despite this difference, all the families discussed similar practices in terms of digital technology, there were technological solutions but the most significant strategy was proximity; for all the younger children, computer use was in a shared living space. There was a move away from these shared practices to more privacy as young people got older and the mother's role was renegotiated.

As mentioned above siblings also mediate information for each other. This involves working together, sharing knowledge and teaching each other. This was viewed positively by the young people: "I like it especially when we have help from each other" (Mia).

For many of the young people other figures such as aunts, uncles, grandparents or family friends played an important role. Mia and Isla's grandparents set projects for them and passed on family knowledge and traditions; Eleanor's granddad occupied the same role as some fathers; he was described variously as her French tutor and her fellow student, and Siobhan's friends shared knowledge with her daughter. Different families have different practices but the information literacy is inherently social.

Beyond the family, participants talk about their information practices as part of a home educating community or communities. The children learn from older children: 
They've got you know things that they'll tell them and show them. It's really good then, different levels, ages, experiences.

(Karen)

It was clearly significant for these young people to be part of a home educating community in terms of friendships but the importance of this in terms of information practices is not developed within this current study. We can see this when Eleanor contrasts her experience in home education with her experiences at college: "it's good to have some kind of classroom experience of working together, of being in a group". She also describes collaborative learning as part of home education but it seems to be a different quality of experience. Further research is needed to understand this aspect more fully.

One of the first things I did was get into this group of other home educated girls and we all wrote stories together and stuff like that.

The home education community was more demonstrably significant for the mothers for sharing and learning in person and online. There was evidence of a strong community: "I think I've just I've realised how much I draw on it recently and it's... like do you choose to be part of it or not" (Siobhan). There was some evidence of this as an apprenticeship: "a home edder told me when I first started" (Karen). Sarah, who had been home educating the longest, could not identify how she had changed but the others who had been home educating between sixteen and two years all articulated how they felt they had changed. The mothers also sought out those who shared the same philosophical position ("you need to find out who thinks like you" (Emma)) and discussed how they had been changed by home educating: "I'm learning more this time around than I ever did" (Karen). There are also shared strategies which seemed to link to identities, for example, Siobhan recounts how she learnt how to respond to the LEA:

So that's when a friend said you just have to write at the top we are autonomous or self-led and that's when I started to think about what terms I would use.

There is also evidence within the interviews of a collaborative meaning-making process, where the interviewer and the participants together build on their experiences of information literacies. This helps to build on the conception of information literacy as constructed. In this way, Eleanor moves from seeing herself as independent in her information literacies to recognising the significance of others: "pretty much by myself... My granddad, that's a good point my granddad actually is a big figure".

\section{Discussion}

\subsection{Understanding home educated families' digital literacy practices}

The young people in this study paralleled Shenton and Dixon's (2003) findings in identifying books, the Internet and people as their main information sources. The analysis of the interviews clearly shows the central importance of the Internet to home educating families supporting Hanna (2012), but also reflecting the pattern of high Internet use for many children in the United Kingdom (OFCOM, 2012). The parents in this study all felt confident in their use of the Internet and in being 
able to help their children, contrasting with the forty four percent of parents in the OFCOM survey who say their children know more than them about the Internet. Lees' (2011) work on how parents discover home education highlights the importance of the Internet and this is reflected by the parents in this study.

The children's acquisition of digital skills seemed to be through social practice; it involved not just learning by experimentation but by modelling and by shared family rules. This parallels McTavish's (2009) findings on the home digital literacies of school-attending children. There was a perception among the families that home educated children were more digitally literate and had a more "authentic" experience of using computers. As mentioned above it is possible that these children's experiences of information literacy are actually similar to the outof-school practices of school-attending children.

\subsection{Information skills model versus holistic and potentially transformative information practices}

There is a powerful narrative within existing research that home educated children are independent learners adept at handling information (Fortune-Wood, 2005; Thomas and Pattison, 2007; Dowty, 2000). The young people in these interviews have similar constructions of themselves as confident and information literate. However, this was not a stable construction. On reflection, they expressed more uncertainty and talked about their difficulties as well as recognising the collaborative nature of their learning and information use. The interviews therefore became a place for some of the children to reflect on their literacies. This is similar to findings that uncertainty is a way for school children to become more information literate (Hongisto and Sormunen, 2010) and on the importance of reflection (Herring, 2010).

Lupton and Bruce's (2010) kernel model of information literacy could provide a way of interpreting home educating families' information literacies. In this way, the young people move from seeing themselves as competent, to recognising the skills they use, to finally feeling that their information literacy is collaborative. There was evidence that information literacies were socially constructed both within each family and within the home educating community. This sense of information literacy as socially constructed was something participants struggled to express and is an area which calls for further exploration.

The third and outer layer of this model is the transformative and this potentially also provides a way to view these home educating families' information literacies. There was a tendency for the home educators in this study to favourably contrast their information literacy practices to school practices. This approach could be framed as a challenge to the orthodoxy of information literacy in education. We can see this played out if we look at the role of gender in these families: the mothers are responsible for the hidden holistic information literacy, while the fathers are responsible for the more knowledge-based strand. This is only one interpretation, which would need to be substantiated by further research. 


\subsection{Communities of practice as a way to understand home educating families' information literacy}

Lloyd $(2007,2005)$ uses communities of practice as a way to understand workplace information literacy and this study suggests that they could also provide a way to understand the home educating families' information literacy. This study therefore supports Safran (2010) in seeing home educating parents as a community of practice. The mothers in this study meet Wenger's descriptions (1998) of a community practice. They have a shared identity seen, for example, in the use of "home edder", a term that does not seem to be used outside of the community. They have the shared activities and shared strategies of educating their children and learning how to be better home educators.

It is also possible to support Thomas and Pattison's (2012) interpretation of the families as a community of practice. The frequent use of "we" demonstrates a shared identity; they are involved in the joint enterprise of learning and have shared practices. The model helps us understand the information literacy relationship between the mothers and their children. It is an apprenticeship, as well as co-learning, and this helps to expand on the ambiguous role the mothers seem to occupy as teachers and not teachers.

The model of the family as a community of practice may also help our understanding of how home educating mothers control and mediate information for their children. This is exemplified by the narrative of Eleanor and her mother, where the significance of the family as the site of learning is lessened as the young person grows up. Hanna (2012) discusses how children move away from family networks as they get older. The two oldest children in this study have both moved outside of their family's community of practice to attend college "I'm not an artist I can't show her any more" (Siobhan).

The question of whether the children are part of a wider home educating community of practice is not fully answered here. The local home educating community was very significant for the children with evidence of a shared identity and of shared activity although this seems to be framed as socialization. However, there is not consistent evidence of shared strategies.

\section{Conclusion}

The interviews provided rich narratives and a wealth of detail about these families' information literacy experiences. However, they were only five families and so it was unrealistic to expect to develop a framework from this small number of interviews. For example, the interviews show a continuum whereby younger children view the Internet in more passive terms than older children but we cannot generate theory from this. Despite this, there is the potential for these interviews to inform both research and practice.

Further research in this area would be beneficial in developing the themes that emerged from this research, whether by case studies of home educating families or by focusing on home educating children as they transition from home to university, college or work. There were also particular areas that would reward further investigation. There was a gap in the research in how far home educated children were a part of communities of practice outside their family groups. The 
importance of reflection as part of information literacy was an important theme in this research and this would also merit further investigation. In the same way, the study showed the difficulty of conceptualising information literacy practices outside of information seeking and it would repay further research to find ways to explore these practices more widely.

The research could also have the potential to inform library and information practitioners, particularly those working in public libraries, about home education which has received little attention from the sector. This may include, but would not be limited to, a recognition that home educated families have diverse experiences of information literacy that cannot be understood simply by a reference to a skills model.

Beyond this, perhaps the most potentially interesting finding was whether these families' information literacy practices could be seen as disrupting and challenging orthodox models more generally. In this way, it could encourage practitioners to consider how information literacy could be facilitated rather than taught in other settings.

It can be hoped that the research process in itself was valuable for the home educators involved, for example in the positive response to the interview transcripts, and the evidence of meaning-making within the interviews. However, the families provided little feedback from the dissemination of the research suggesting that the findings may not have resonated with them, although there were some insights, such as the value of reflection in the information literacy practices of home educating families, which may be helpful for the community.

This research is also an exploration of information literacy experiences in a domain that researchers in the discipline have not previously considered. It therefore answers Tuominen, Savolainen, and Talja's (2005) call for information literacy research in new environments.

\section{References}

ACRL (Association of College and Research Libraries) (2000) Information literacy competency standards for higher education [online]. URL: http://www.ala.org/ala/mgrps/divs/acrl/standards/standards.pdf [accessed 6.2.15].

Arora, T. (2002) Research report on home education in Kirklees [online]. University of Sheffield. URL: http://ahed.pbworks.com/w/file/1553329/Arora\%202002.doc [accessed 6.2.15].

Badman, G. (2009) Report to the Secretary of State on the review of elective home education in the United Kingdom [online]. London: HMSO. URL: https://www.education.gov.uk/consultations/downloadableDocs/PDF\%20FINAL \%20HOME\%20ED.pdf [accessed 6.2.15].

Bawden, D. (2001) Information and digital literacies: A review of concepts. Journal of Documentation, 57(2), 218-259. 
Blok, H. and Karsten, S. (2011) Inspection of home education in European countries.European Journal of Education, 46(1): 138-152.

Bruce, C. (1997) The seven faces of information literacy. Adelaide: Auslib Press.

Charmaz, K. (2006) Constructing grounded theory: A practical guide through qualitative analysis. London: Sage.

Christensen, P and James, A. (2008) Introduction: researching childhood and childhood cultures of communication. In: Christensen, P. and James, A. (eds.) Research with children: Perspectives and practices. $2^{\text {nd }}$ ed. New York: Routledge. $1-9$.

Cogan, M. F (2010) Exploring academic outcomes of homeschooled students. Journal of College Admission, (208), 18-25.

Davidson, C. (2012) Seeking the green basilisk lizard: acquiring digital literacy practices in the home. Journal of Early Childhood Literacy [online], 12(1): 24-45. http://dx.doi.org/10.1177/1468798411416788 [accessed 6.2.15]

Dell Clark, C. (2011) In a younger voice: doing child-centered qualitative research. Oxford: Oxford University Press.

Dowty, T. (2000) Free range education : How home education works. Stroud: Hawthorn.

Duncombe, J. and Jessop, J. (2012) Doing "rapport" and the ethics of faking friendship. In: Miller, T., Birch, M., Mauthner, M. and Jessop, J. (eds.) Ethics in qualitative research. $2^{\text {nd }}$ ed. London: Sage. 108-121.

Education Act 1996 [s437-443]

Edwards, R. and Mauthner, M. (2012) Ethics and feminist research theory and practice. In: Miller, T., Birch, M., Mauthner, M. and Jessop, J. (eds.) Ethics in qualitative research. $2^{\text {nd }}$ ed. London: Sage. 14-28.

Fortune-Wood, J. (2000) Doing it their way: home-based education and autonomous learning. Nottingham: Educational Heretics.

Fortune-Wood, M. (2005) The face of home-based education 1: Who, why and how? Nottingham: Educational Heretics.

Gabb, S. (2005) Homeschooling: a British perspective. In: Cooper, B. (ed.) Homeschooling in full view: A reader. Charlotte: Information Age Publishing. 199-219.

Gaither, M. (2009) Homeschooling in the USA: past, present, future. Theory and Research in Education, 7(3), 331-346.

Glaser, B. and Strauss A. (1967) The discovery of grounded theory : strategies for qualitative research. New York: Aldine de Gruyter.

Glaser, B. (2002) Constructivist grounded theory? Forum Qualitative Sozialforschung / Forum: Qualitative Social Research [online], 3(3). URL: http://www.qualitative-research.net/index.php/fqs/article/view/825 [accessed 6.2.15]. 
Gross, M. and Latham D. (2009) Undergraduate perceptions of information literacy: defining, attaining, and self-assessing skills. College \& Research Libraries [online], 70(4), 336-350. URL: http://crl.acrl.org/content/70/4/336.short [accessed 6.2.15].

Guba, E. and Lincoln, Y. (1985) Naturalistic inquiry.Beverly Hills, California; London: Sage.

Hanna, L. (2012) Homeschooling education longitudinal study of methods, materials, and curricula. Education and Urban Society, 44(5), 609-631.

Herring, J. (2009) A grounded analysis of year 8 students' reflections on information literacy skills and techniques. School Libraries Worldwide [online], 15(1), 1-13. URL: http://www.iasl-online.org/files/jan09_herring.pdf [accessed 6.2.15].

Herring, J (2010) Year 12 students' use of information literacy skills: a constructivist grounded analysis. In: Lloyd, A. and Talija, S. (eds.) Practising information literacy: bringing theories of learning, practice and information literacy together. Wagga Wagga: CIS. 143-166.

Herring, J. (2011) Year 7 students, information literacy, and transfer: A grounded theory. School Library Research [online], 14, 91-121. URL:

http://www.ala.org/aasl/sites/ala.org.aas1/files/content/aaslpubsandjournals/slr/vol 14/SLR_Year7Students_V14.pdf [accessed 6.2.15].

Holstein, J. and Gubrium J. (2004) The active interview. In: Silverman, D. (ed.) Qualitative research : theory, method and practice. $2^{\text {nd }}$ ed. London: Sage Publications. 140-161.

Holt, J. (1977) Instead of education: ways to help people do things better. Harmondsworth: Penguin.

Holt, J. (1991) Learning all the time. Ticknall: Education Now

Hongisto, H. and Sormunen E. (2010) The challenges of the first research paper: observing students and the teacher in the secondary school classroom. In: Lloyd, A. and Talija, S. (eds.) Practising information literacy: bringing theories of learning, practice and information literacy together. WaggaWagga: CIS. 68-95.

Hopwood, V., O'Neill, L., Castro, G. and Hodgson, B. (2007) The prevalence of home education in England: a feasibility study. Nottingham: York Consulting Ltd for the Department of Education and Skills.

Johnson, A., Sproles, C. and Detmering, R. (2011) Library instruction and information literacy 2010. Reference Services Review, 39(4), 551-627.

Johnson, G. (2010) Young children's internet use at home and school: patterns and profiles. Journal of Early Childhood Research, 8(3), 282-293.

Kapitzke, C. (2003) Information literacy: A positivist epistemology and a politics of (out)formation. Educational Theory [online], 53(1): 37-53. URL: http://eprints.qut.edu.au/ [accessed 6.2.15].

Kitzinger, J. (1995) Qualitative research: introducing focus groups. British Medical Journal, 311(7000), 299-302. 
Kunzman, R. and Gaither, M. (2013) Homeschooling: a comprehensive survey of the research. Other Education [online], 2(1), 4-59. URL: http://www.othereducation.org/index.php/OE/article/view/10 [accessed 6.2.15].

Lees, H. (2011) The gateless gate of home education discovery: What happens to the self of adults upon discovery of the possibility and possibilities of an educational alternative? [PhD thesis online]. Birmingham: University of Birmingham. URL: http://etheses.bham.ac.uk/1570/ [accessed 6.2.15].

Lewis, R. (2009) Recruiting parents and children into a research project: a qualitative exploration of families' decision-making processes. International Journal of Social Research Methodology, 12(5), 405-419.

Limberg, L. and Sundin, O. (2006) Teaching information seeking: relating information literacy education to theories of information behaviour. Information Research [online], 12(1). URL: http://www.informationr.net/ir/121/paper280.html [accessed 6.2.15].

Lipu, S. (2010) Exploring information literacy from feminist perspectives. In: Lloyd, A. and Talija, S. (eds.) Practising information literacy: bringing theories of learning, practice and information literacy together. WaggaWagga: CIS. 331356.

Lloyd, A. (2005) Information literacy different contexts, different concepts, different truths? Journal of Librarianship and Information Science, 37(2), 82-88.

Lloyd, A. (2007) Learning to put out the red stuff: Becoming information literate through discursive practice. The Library Quarterly, 77(2), 181-198.

Lloyd, A. (2010) Information literacy landscapes:information literacy in education, workplace and everyday contexts. Oxford: Chandos.

Lois, J. (2006 ) Role strain, emotion management, and burnout: homeschooling mothers' adjustment to the teacher role. Symbolic Interaction, 29(4), 507-530.

Lupton, M and Bruce, C., (2010) Windows on information literacy worlds: Generic, situated and transformative perspectives. In: Lloyd, A. and Talija, S. (eds.) Practising information literacy: bringing theories of learning, practice and information literacy together. Wagga Wagga: CIS. 4-27.

Martin-Chang, S., Gould, O. and Meuse, R. (2011) The impact of schooling on academic achievement: Evidence from homeschooled and traditionally schooled students. Canadian Journal of Behavioural Science / Revue Canadienne Des Sciences Du Comportement, 43(3), 195-202.

Mayall, B. (2008) Conversations with children: generational issues. In: Christensen, P. and James, A. (eds.) Research with children: Perspectives and practices. $2^{\text {nd }}$ ed. New York : Routledge. 109-124.

Mauthner, N., and Doucet, A. (2003) Reflexive accounts and accounts of reflexivity in qualitative data analysis. Sociology, 37(3), 413-431.

McTavish, M. (2009) "I get my facts from the internet": A case study of the teaching and learning of information literacy in in-school and out-of-school contexts. Journal of Early Childhood Literacy, 9(1), 3-28. 
Meighan, R. (1992). Learning from home-based education: an education now special report. Ticknall: Education Now.

Meighan, R. (1995) Home-based education effectiveness research and some of its implications. Educational Review, 47(3), 275-287.

Meyers, E.,Nathan, L. and Saxton, M. (2007) Barriers to information seeking in school libraries: conflicts in perceptions and practice. Information Research [online], 11(2). URL: http://dialnet.unirioja.es/servlet/articulo?codigo=2209551 [accessed 6.2.15].

Miller, J. and Glassner, B. (2011) The inside and the outside: finding realities in interviews. In: Silverman, D. (ed.) Qualitative research : theory, method and practice. $3^{\text {rd }}$ ed. London: Sage. 131-148.

Miller, T. and Bell, L. (2012) Consenting to what? Issues of access, gate keeping and informed consent in T. Miller, M. Birch, M. Mauthner and J. Jessop (eds.) Ethics in qualitative research ( $2^{\text {nd }}$ ed., Pp. 61-75).London, United Kingdom, Sage.

Monk, D. (2004) Problematising home education: challenging 'parental rights' and 'socialisation'. Legal Studies, 24(4), 568-598.

Morton, R. (2010). Home education: constructions of choice. International Electronic Journal of Elementary Education [online], 3(1). URL: http://www.iejee.com/3_1_2010/45_56.pdf [accessed 6.2.15].

Morton, R (2011) Balancing pleasure and pain: the role of motherhood in home education. [PhD thesis online]. Warwick: University of Warwick. URL: http://webcat.warwick.ac.uk/record=b2568908 S1 [accessed 6.2.15].

Oliver, P. (2010) The student's guide to research ethics. $2^{\text {nd }}$ ed. Maidenhead: McGraw-Hill / Open University Press.

OFCOM. (2012) Children and parents: media use and attitudes report [online]. London: OFCOM. URL:

http://stakeholders.ofcom.org.uk/binaries/research/medialiteracy/oct2012/main.pdf [accessed 6.02.15].

Pennings, R., Seel, J., Neven Van Pely, D.,Sikkink, D. and Weins, K. (2011) Cardus education survey. Hamilton: Cardus.

Puddephatt, A. (2006) An interview with Kathy Charmaz: on constructing grounded theory, Qualitative Sociology Review [online], 2(3), 5-20. URL: http://www.qualitativesociologyreview.org/ENG/Volume5/QSR_2_3_Interview.p df [accessed 6.2.15].

Ray, B. (2010) Academic achievement and demographic traits of homeschool students: a nationwide study, Academic Leadership Journal [online], 8(1), 17-42. URL:

http://contentcat.fhsu.edu/cdm/compoundobject/collection/p15732coll4/id/835/rec /1 [accessed 6.2.15].

Rothermel, P. (2002) Home-education: rationales, practices and outcomes $[\mathrm{PhD}$ thesis online]. Durham: University of Durham. URL:

http://pjrothermel.com/phd/Home.htm [accessed 6.2.15]. 
Rothermel, P. (2011) Setting the record straight: interviews with a hundred British home educating families. Journal of Unschooling and Alternative Learning [online], 5(10), 20-57. URL:

http://jual.nipissingu.ca/wpcontent/uploads/sites/25/2014/06/v52102.pdf [accessed 6.2.15].

Rudner, L. (1999) Achievement and demographics of home school students: 1998. Education Policy Analysis Archives [online], 7, 8. URL: http://epaa.asu.edu/ojs/article/viewFile/543/666 [accessed 6.2.15].

Safran, L. (2008) Exploring identity change and communities of practice among long term home educating parents [PhD thesis online]. Milton Keynes: Open University. URL: http://www.theotherwiseclub.org.uk/leslies-thesis.html [accessed 6.2.15].

Safran, L. (2010) Legitimate peripheral participation and home education. Teaching and Teacher Education, 26(1), 107-112.

Savolainen, R. (1993) The sense-making theory: Reviewing the interests of a user-centered approach to information seeking and use. Information Processing and Management, 29(1), 13-28.

Society of College, National and University Libraries (SCONUL) (2011) The SCONUL seven pillars of information literacy: Core model [online]. URL: www.sconul.ac.uk/sites/default/files/documents/coremodel.pdf [accessed 10.10.15].

Select Committee on Children, Schools and Families (2009) The Review of Elective Home Education. London: HMSO.

Shenton, A. and Dixon, P (2003) Models of young people's information seeking. Journal of Librarianship and Information Science, 35(1), 5-22.

Smith, M. (2010) Young people: a phenomenographic investigation into the ways they experience information [ $\mathrm{PhD}$ thesis online]. Loughborough: University of Loughborough. URL: https://dspace.lboro.ac.uk/dspace-jspui/handle/2134/6632 [accessed 6.2.15].

Thomas, A. and Pattison, H. (2007) How children learn at home. London: Continuum.

Thomas, A. and Pattison, H. (2012) Informal home education: Philosophical aspirations put into practice. Studies in Philosophy and Education, 32(2), 141154.

Tuominen, K.,Savolainen, R. and Talja, S. (2005) Information literacy as a sociotechnical practice. The Library, 75(3), 329-345.

Webber, S. and Johnston, B. (2000) Conceptions of information literacy: new perspectives and implications. Journal of Information Science, 26(6), 381-397.

Webb, J. (1999) Those unschooled minds home-educated children grow up. Nottingham: Educational Heretics.

Webb, S. (2011) Elective home education. Stoke-on-Trent: Trentham Books. 
Wenger, E. (1998) Communities of practice: Learning, meaning, and identity. Cambridge: Cambridge University Press.

Wilkinson, S. (1998) Focus groups in feminist research: power, interaction, and the co-construction of meaning. Women's Studies International Forum, 21(1), $111-125$.

\section{The Occasion}

The dissertation on which this research paper was based was submitted to the University of Sheffield in partial fulfilment of the requirements for the degree of MA Librarianship. The dissertation was awarded the LIRG student prize for 2014.

\section{Acknowledgement}

This research would not have been possible without the five home educating families who shared their stories.

\section{Open access and copyright}

Library and Information Research is an open access journal. A freely available copy of this paper may be downloaded from the journal's website: http://www.lirgjournal.org.uk.

Copyright and associated moral rights in works published in Library and Information Research are retained by the author(s) but this paper may be used freely, with proper attribution, in educational and other non-commercial settings. 